\title{
Unbundling interest rate and bank credit nexus on income inequality: structural break analysis from Nigeria
}

\author{
Bosede Ngozi Adeleye
}

Department of Economics and Development Studies, Covenant University, Ota, Nigeria; Regional Centre of Expertise, Ogun, Nigeria and Centre for Economic Policy and Development Research, Covenant University, Ota, Nigeria

\begin{abstract}
Purpose - Income inequality stalls economic growth with undesirable socio-economic consequences. Despite various measures targeted towards reducing the inequality gap, disparities in income distribution persist in Nigeria. Therefore, this study aims to explore a new line of argument to the finance mechanism in reducing income inequality.

Design/methodology/approach - The study uses time-series data on Nigeria from 1980 to 2015 with analysis conducted using the autoregressive distributed lag-error correction model approach of Pesaran et al. (2001).

Findings - The results show amongst others that the channel of real interest rate on income inequality is through bank credit, real interest rate has an indirect relationship to income inequality and bank credit has an equalising impact on income inequality when the model is augmented for a structural break. The results show amongst others, that, on average, ceteris paribus, a 1\% point increase in the real lending interest rate is associated with a $0.45 \%$ decline in the volume of bank credit.

Originality/value - This paper engages a new line of argument by unbundling how financial intermediation impacts on income inequality. The extant literature submits that finance directly impacts income inequality, whereas this study investigates further to show that interest rate impacts income inequality through bank credit. That is, the transmission mechanism by which finance affects income inequality is modelled and analysed.
\end{abstract}

Keywords Interest rate, Bank credit, Income inequality, Structural break, ARDL-ECM

Paper type Research paper

\section{Introduction}

In recent times, inclusive policy debates about income inequality have intensified with concerns on reducing the widening gap. From essays on income inequality, one of its principal determinants is access to finance (Levine, 2008; Demirgüç-Kunt and Levine, 2009; Agnello et al., 2012). Galor and Moav (2006) theorise that the development of financial markets will facilitate more human capital accumulation by low-income families to mitigate income inequality. The role of finance is corroborated by Piketty (2014), who shows that

JEL classification - D63, F36, G20, G21, O15, O55

This study draws insights from the author's Doctoral Thesis. Thus, comments received from the seminars at the Departmental and College Levels are appreciated.

Funding: Not Applicable

Conflicts of interest: None

Availability of data and material: Data will be made available upon request 
when the rate of return (the interest rate) exceeds output growth inequality widens as accumulated wealth grows faster than wages. The reason is that the rich with inherited wealth save only a portion of their income from capital, which grows more quickly than the economy as a whole. Such persons inevitably become creditors and more dominant over those who own nothing, which worsens inequality. Hence, the rate of return plays a significant role in the finance-inequality theory as it illuminates a variety of direct and indirect mechanisms through which changes in the operation of the financial sector can exacerbate or reduce the inequality of pecuniary opportunity (Beck et al., 2007; Levine, 2008; Demirgüç-Kunt and Levine, 2009). This discourse, therefore, serves as the study's motivation for the examination of income inequality within a financial system framework.

Relative to the studies on poverty levels (Aigbokhan, 2000, 2008; Osahon and Osarobo, 2011; Nuruddeen and Ibrahim, 2014; Kolawole et al., 2015; Ogbeide and Agu, 2015), there are sparse studies on income inequality in Nigeria, which has been rising sharply. Rising inequality leads to less stable and more violent and conflictive societies with protests centred around issues such as corruption, rising utility prices, growing inequality and the visibly-increasing concentration of economic power in multi-nationals (Africa Tax and Inequality Report, 2014).

Considered as one of the fastest-growing economies in the world (AfDB, 2012; Africa Tax and Inequality Report, 2014; World Bank, 2015) and despite the abundant human and natural resources, Nigeria has been witnessing an increasing rate of socio-economic challenges. Some of which are not limited to the rising farmers-pastoralists conflicts from the Northern and South-Western parts of the country, which claimed several lives led to loss of incomes and livelihoods. Similarly, violent conflicts from militant sects based in the South-South Niger Delta oil region, Boko Haram Islamic militant sect from the North East and the Middle Belt tribal conflicts have undermined the economic power of the people and country in general (Mercy Corps, 2015). Besides, high rate of poverty both at the regions and at the national level, high unemployment rate, high-income inequality, low-quality human capital, a high percentage of the population on welfare and high emigration in the face of harsh economic realities (Odedokun and Round, 2001; Ogbeide and Agu, 2015) are the stark realities of present-day Nigeria.

Figure 1 reveals the pattern of income inequality in Nigeria. In 1980, the Gini index was 50.61 and rose to 60.07 in 1992, dipped slightly to 58.77 in 1996, climbed again to 58.87 in 2009 before a downward trend to 48.83 in 2015.

On documented issues, inequality moderates with an increase in per capita gross domestic product (GDP) (van der Hoeven, 2010; Delis et al., 2014; Davtyan, 2016; Adeleye et al., 2017). Some studies argue that inequality reduces via human capital through equal access to quality education at all levels (Barro, 2008; Lo Prete, 2013). Inequality declines through the eradication of corruption and the existence of quality institutions (Kar and Saha, 2012; Li and $\mathrm{Yu}, 2014)$. In the same vein, some argue that inequality increases with inequitable government spending on social infrastructure/development (Chatterjee and Turnovsky, 2012); high unemployment rate (Østergaard, 2013) and trade openness (Dastidar, 2012), just to mention a few.

In contributing to the inequality literature, this study situates within three theoretical frameworks, namely, the extensive and intensive margin theories and the liquidity theory. The extensive margin theory borders on broadening the availability of financial services to individuals excluded from the use of financial services due to price or discrimination (Odhiambo, 2014; Orji et al., 2015; Chiwira et al., 2016). That is, financial development will increase the economic opportunities of those who are at a disadvantage and reduce the cross-dynasty persistence of relative incomes (Becker and Tomes, 1979, 1986; Greenwood 


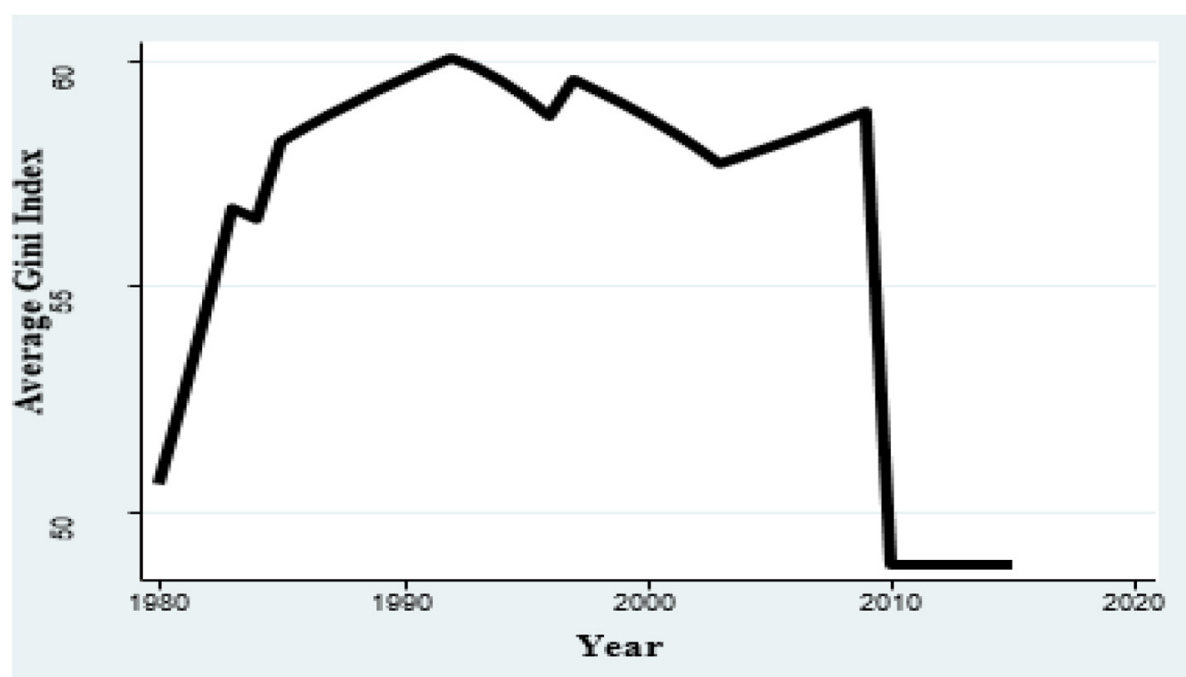

Source: Author's Computation from Lahoti et al. (2016)

\section{Structural break analysis}

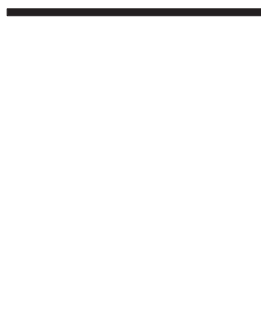

Figure 1. Gini index, Nigeria $(1980-2015)$

and Jovanovic, 1990; Bae et al., 2012; Batabyal and Chowdhury, 2015). The intensive margin theory states that finance can affect inequality through an indirect mechanism and directly by enhancing financial services of those already accessing them and these are usually highnetworth individuals and well-established organisations (Chipote et al., 2014; Olusegun et al., 2014). Correspondingly, the liquidity constraints theory positions that liquidity constraints impede the business opportunities of the poor, thus exacerbating income inequality among economic agents (Evans and Jovanovic, 1989; Holtz-Eakin et al., 1994; Black and Lynch, 1996; Blanchflower and Oswald, 1998; McKenzie and Woodruff, 2006).

On the role of credit, the financial sector is an engine for growth of which the empirical literature focusses on the importance of the finance-growth nexus for sustainable development. However, recent studies have started a discourse about how financial reforms or financial liberalisation can affect income inequality. Finance or credit availability shapes the gap between the rich and the poor and augments the extent to which that gap widens or contracts across dynasties. Also, credit shocks to some economic agents can affect the distribution of capital, adjust the rate of economic growth and the quest for production inputs (particularly labour) with adverse consequences on poverty and income distribution (Piketty, 2014). This study limits credit to domestic credit to the private sector from the banking system without capturing public sector credits. This indicator is appropriate because the inclusion of public sector credit bloats the volume of credit exposure in the economy and clouds the actual size of the loan extended to the private sector. The increase in lending is one of the probable outcomes of financial reforms and signifies the stability of any financial system (Balassa, 1989; Adeleye et al., 2018). Economic growth and development hinges on the extent to which households and firms have access to credit (Bae et al., 2012). Thus, credit is the contractual agreement in which a borrower receives something of value now and agrees to repay the lender at a future date, generally with interest. The term also refers to the borrowing capacity of an individual or company and it is the amount of loans and advances made available by a bank or financial 
intermediary to a person or a firm. It is also the volume of funds financial institutions are willing to provide to individuals or firms (IMF, 2010).

Some studies (Adusei, 2013; Boateng and Abdulrahman, 2013; Frey and Volz, 2013; Chiwira et al., 2016) capture credit growth by the volume of domestic credit to the private sector, which is a function of several macroeconomic factors. As an economy witnesses rapid development of its financial sector, credit growth occurs (Iossifov and Khamis, 2009). However, in a bid to foster financial deepening is the risk of triggering a "credit boom" defined as when some measure of credit experience extreme deviations from its trend, with the implicit supposition that such abnormalities are not supported by fundamentals (Iossifov and Khamis, 2009). An essential outcome of the credit boom literature is that incidences of excessive credit growth tend to be synchronised across countries (IMF, 2010). Finally, the observed growth rate of credit depends on the development of the financial sector and driven by the interaction of the factors of demand and supply.

Given this background and while aligning with the 2030 United Nations Sustainable Development Goal (SDG) 10, which aims to reduce inequality within and among countries, this paper contributes to the finance-inequality literature in four ways. Firstly, by bridging two contemporary literature - the bank performance literature and the finance-inequality literature. The bank performance literature expounds the determinants of credit, while the finance-inequality essay explains how finance or reforms within the financial system impacts on income inequality. Secondly, by modifying the transmission mechanism through which funding affects income inequality. The finance-inequality literature posits that the interest rate has a direct relationship with income inequality (Delis et al., 2014). Contrarily, this study hypotheses that rather than a direct link, the interest rate should have an indirect relationship to income inequality.

Thirdly, the linear dependence between the interest rate and domestic credit to the private sector is capable of producing misleading results. Hence, the current effort modifies the scholarship model by adopting a two-equation error correction model (ECM) in explaining the channel of influence by which bank credit impacts on income inequality. The study postulates that there will be a decrease in the volume of funds available for lending if the lending rate increases equivalent to a reduction in the real lending rate, having a positive effect on the quantity of loanable funds. Sifting through empirical literature, this is a new direction of enquiry, which, to the best of knowledge, has not been sufficiently explored in the empirical surveys. Finally, this paper shows that bank credit has an equalising impact on income inequality by augmenting the inequality model due to the evidence of a breakpoint. The rest of the paper is structured as follows. Section 2 presents the empirical models and data; Section 3 discusses the results with robustness checks, while Section 4 concludes with policy recommendations.

\section{Model and data}

\subsection{Theoretical model}

The interest rate is a financial instrument that plays a critical role in most theories of tenacious income inequality. In this section, an attempt is to model the indirect relationship between it and income inequality contrary to the direct relationship postulated in the empirical literature ( $\mathrm{Li}$ and $\mathrm{Yu}, 2014$ ). From the traditional financeinequality literature (Greenwood and Jovanovic, 1990; Levine, 2008; Demirgüç-Kunt and Levine, 2009), income inequality is a function of financial sector indicators and the theoretical model is given as: 


$$
I N E Q_{t}=f\left(X_{t}\right)
$$

where $I N E Q_{t}$ is the measure of income inequality and $X_{t}$ is a set of variables characterising financial sector regulations occasioned by financial reforms or liberalisation - of which domestic credit to the private sector is a variable.

From equation (1), the probable influence of interest rate on income inequality seems less challenging to predict. That is, the reduction in the lending rate by regulatory policies enhances financial intermediation and increases the volume of lending (credit). In line with the theoretical literature allows individuals at the lower end of the income distribution to have easier access to capital and to fund their business investment ideas more efficiently and at a reduced cost. Therefore, equation (1) is modified to reflect that channel of influence through which interest rate impacts on income inequality, which is through credit (a measure of financial depth and stability), as the increase in credit is an outcome of financial liberalisation (Gine and Townsend, 2004). Empirical evidence reveals that regulatory policies (such as interest rate liberalisation, reserve requirements and removal of entry barriers) reduce credit market constraints and enhance the rate of both human and physical capital accumulation of poor households. Thus, equation (1) modifies into a two-equation model:

$$
C R_{t}=f\left(\text { int }_{t}, Z_{t}\right)
$$

and

$$
I N E Q_{t}=f\left(C R_{t}\right)
$$

where $C R_{t}$ is the volume of credit and $i n t_{t}$ is the interest rate; $Z_{t}$ is a set of financial and macroeconomic variables.

\subsection{Empirical models}

2.2.1 Autoregressive distributed lag model. Following both the theoretical and empirical literature and aligning with this study's theoretical framework, the empirical model is modified to show the channel of influence of the real interest rate on income inequality through bank credit. Thus, following Kripfganz and Schneider (2016) and Adeleye et al. (2018), the generalised autoregressive distributed lag (ARDL) $((p, q,[\ldots, \ldots, q))$ two-equation model is stated as:

$$
\begin{gathered}
\ln B C_{t}=\omega_{0 i}+\sum_{i=1}^{p} \delta_{i} \ln B C_{t-i}+\sum_{i=0}^{q} \phi R_{t-i}+\sum_{i=0}^{q} \theta_{i}^{\prime} \boldsymbol{Z}_{t-i}+\boldsymbol{\varepsilon}_{\mathrm{t}} \\
\ln \operatorname{GINI}_{t}=\lambda_{0 i}+\sum_{i=1}^{p} b_{i} \ln \operatorname{lINI}_{t-i}+\sum_{i=0}^{q} \zeta_{i} B C_{t-i}+\sum_{i=0}^{q} \Psi_{i}^{\prime} \boldsymbol{K}_{t-i}+\boldsymbol{v}_{t}
\end{gathered}
$$

where $\ln B C$ is the natural logarithm of bank credit; $R$ is the real lending interest rate; GINI is the natural logarithm of Gini index; $\omega, \lambda$ are constant terms; $\delta, b, \phi, \zeta$ are parameters; $i$, countries, $1,2, \ldots, N ; t$, time, $1,2,[\ldots], T, \Theta^{\prime}{ }_{i} Z_{i t}, \Psi^{\prime}{ }_{i} \boldsymbol{K}_{i t}$ are vectors of observed time-variant control variables and their regression coefficients.

The dependent and explanatory variables are allowed to be purely $I(0)$ or $I(1)$ or cointegrated; $p, q$ are optimal lag orders; $\boldsymbol{\varepsilon}_{-t}, \boldsymbol{v}_{-t}$ are vectors of the error terms unobservable zero-mean white noise vector process (serially uncorrelated or independent). 
Equation (4) addresses the issue of whether bank credit is stimulated by real lending interest rate while equation (5) discourses the crux of this study, which is to show whether bank credit has an equalising effect on income inequality. Hence, the combination of equations (4) and (5) shows the transmission mechanism by which the real interest rate indirectly impacts on income inequality and also unbundles the rate-credit-inequality nexus. Finally, the inclusion of control variables (Table 2 for full variables list) is to determine whether the effect of the main explanatory variables on the dependent variable still holds after considering the effects of these covariates. It is also important to note that equation (5) accounts for hysteresis or persistence in income inequality consistent with the discussed theoretical and empirical literature.

\subsection{Error correction model and cointegration tests}

2.3.1 Bounds cointegration test. It is imperative to establish the existence of cointegrating relationships among the variables before embarking on the error correction mechanism. This approach is analysed using the ARDL bounds test method as developed by Pesaran et al. (2001). The test is mainly based on the joint $F$-statistic whose asymptotic distribution is non-standard under the null hypothesis of no cointegration against the alternative hypothesis of a cointegrating relationship. The bounds test assumes that the model comprises of both $I(0)$ and $I(1)$ variables and two levels of critical values are obtained. The three options of the decision criteria are as follows:

(1) if the calculated $F$-statistic is greater than the critical value bounds for the upper bound $I(1)$, there is cointegration that is there is a long-run relationship;

(2) if the calculated $F$-statistic falls below the theoretical, critical value for the lower bound $I(0)$ bound, there is no cointegration, hence, no long-run relationship; and

(3) the test is inconclusive if the $F$-statistic falls between the lower bound $I(0)$ and the upper bound $I(1)$.

In the event of cointegrating relationships, the long- and short-run dynamics are analysed using log-log error correction representations specified as:

$$
\begin{aligned}
& \Delta \ln B C_{t}= a_{01}+\gamma\left(b_{1} \ln B C_{t-i}-b_{2} R_{t-i}-b_{3} b m g_{t-i}-b_{4} \ln f_{s} d_{t-i}-b_{5} \ln i n v_{t-i}\right) \\
&+\sum_{i=1}^{p} a_{1} \Delta \ln B C_{t-i}+\sum_{i=0}^{q 1} a_{2} \Delta R_{t-i} \sum_{i=0}^{q 2} a_{3} \Delta b m g_{t-i} \\
&+\sum_{i=0}^{q 3} a_{4} \Delta \ln f s d_{t-i}+\sum_{i=0}^{q 4} a_{5} \Delta \ln i n v_{t-i}+e_{1 t} \\
& \Delta \ln \operatorname{SINI}_{t}= a_{01}+\gamma\left(b_{1} \ln G I N I_{t-i}-b_{2} \ln B C_{t-i}-b_{3} \sec _{t-i}\right)+ \\
& \sum_{I=1}^{P} a_{1} \Delta \ln G I N I_{t-i}+\sum_{i=0}^{q 1} a_{2} \Delta B C_{t-i}+\sum_{i=0}^{q 2} a_{3} \Delta s e c_{t-i}+e_{2 t}
\end{aligned}
$$

where $\Delta$ is the difference operator; $\gamma=1-\sum_{j=1}^{p} \delta_{i}$ is the speed of adjustment coefficient; the terms in 0 represents the error correction term, $E C T$, which is the residual from the longrun equation; $b_{i}$, are the long-run coefficients; $a_{i}$, are the short-run dynamic coefficients of the models' adjustment long-run equilibrium.

Equations (6) and (7) state that $\Delta \ln B C(\Delta \ln$ Gini) depends on its lag, the differenced explanatory variables and also on the equilibrium error term. If the latter is non-zero, then 
the model is out of equilibrium. As $\gamma$ is expected to be negative, its absolute value decides how quickly equilibrium is restored.

2.3.2 Gregory-Hansen structural break cointegration test. Given the structural break in the series of the Gini index (Figure 1), using the bounds cointegration test yields inconsistent outcomes. Therefore, the appropriate cointegration test for the inequality model is the Gregory and Hansen (1996) cointegration test, which is suitable for models with structural breaks. The authors' approach involves testing the null hypothesis of no cointegration against the alternative of cointegration with a single break in an unknown date. The cointegration test is based on extensions of the traditional $A D F, Z \alpha$ and $Z t$ test types. Consequently, the authors formulated three models to accommodate the possibility of structural breaks in the cointegrating relationship. If the null hypothesis is rejected, it implies that the linear combination of the variables exhibits stable properties in the long-run, but with a break. This concept is useful to this study as it helps to define the existence of a long-run equilibrium to which the variables converge over time (Blecker, 2008; Dramani et al., 2012; Borozan, 2017; Sbia et al., 2017). Therefore, to capture the dynamic adjustment of the Gini index in the long- and short-run given a structural break, the augmented ECM representation is specified as:

$$
\begin{aligned}
\Delta \operatorname{gini}_{t}= & a_{0}-\xi\left(\text { gini }_{t-1}-\theta \mathbf{X}_{t}^{\prime}-\vartheta d-\varphi d * \mathbf{X}^{\prime}\right)+b_{0} g i n i_{t}+\sum_{j=1}^{k} b_{j} \mathbf{X}_{j, t-1}^{\prime}+\omega d \\
& +\lambda d * \mathbf{X}^{\prime}+\sum_{i=1}^{P} c_{0 i} \Delta g i n i_{t-1}+\sum_{i=0}^{p} \sum_{j=1}^{k} c_{j i} \Delta \mathbf{X}_{j, t-1}^{\prime}+e_{t}
\end{aligned}
$$

where $\Delta$ is the difference operator, $\gamma=1-\sum_{j=1}^{p} \delta_{i}$ is the speed of adjustment coefficient, $\theta, \vartheta, \varphi$ are the long-run coefficients. $\xi$ is expected to be negative and its absolute value decides how quickly equilibrium is restored. If it is non-zero, then the model is out of equilibrium. $X^{\prime}$ is the vector of explanatory variables ( $B C$ and $\left.s e c\right), d$ is the dummy variable to capture the endogenous breakpoint (it is interacted with each regressor to test for structural changes in the Gini index), $p$ and $k$ are the optimal lag lengths chosen using the Bayesian Information Criteria (BIC).

\subsection{Data}

This section outlines the variables, measurements and data sources. Unless otherwise stated, the variables' scope is from 1980 to 2015 and sourced from Lahoti et al. (2016) Global Consumption Income Project Data set, World Development Indicators of the World Bank (2015) and Global Financial Development Datasets of the World Bank (2016). Because of the structure of the empirical model, the study uses a total of seven variables. The key variables are the real lending interest rate, domestic credit to the private sector bank credit (per cent of GDP), which is the proxy for bank credit and the Gini index, the measure of income inequality. Other control variables are broad money growth (per cent, annual), financial system deposits (per cent of GDP), gross fixed capital formation (per cent of GDP) and secondary enrolment rate (per cent of total). All the variables are as shown in Table 1, including their a priori expectations, measurements, data sources and the model in which they appear.

Similarly, the results of the summary statistics and correlation analysis are shown in Table 2. The output reveals the standard deviation from the Gini index is 4.000 evidencing a huge income dispersion among the population. On the correlation matrix, there is no evidence of multicollinearity among the variables and should such occur, highly collinear variables are not included together in the same equation. 


\section{Results and discussion}

\subsection{Stationarity test}

Before estimating the model, stationarity test is performed using the Dickey-Fuller Generalised Least Squares (DF-GLS) and Phillips-Perron (PP) procedures to ascertain that none of the variables is integrated of order two, that is, $I(2)$ series. The results shown in Table 3 reveal that the variables used in this study are a blend of $I(0)$ and $I(1)$ series, hence the appropriate cointegration test to adopt is the bounds test.

\subsection{Cointegration tests results}

3.2.1 Bounds cointegration results. The results for the bounds cointegration test are shown in the lower panel of Table 5. The $F$-statistics of 5.523 and 6.054 provide evidence against the null hypotheses of no cointegration. Which is rejection at the $1 \%$ level, indicating that there are unique cointegrating relationships among the variables in the models. These results show that in both relationships, the regressors are the forcing variables that move first when a common stochastic shock hits the system. The implication of the above findings is that: bank credit and the Gini index follow changes in these indicators.

3.2.2 Gregory-Hansen cointegration results. In Table 4, the outcome of the Gregory and Hansen (1996) cointegration test shows that the null hypothesis of no cointegration is rejected at the 5\% significance level across the three models. Also, in absolute terms, the test statistics from the $\mathrm{Zt}$ are lower than those of the ADF statistics for Models 1 and 2 and given

\section{Table 1.}

\section{Variables'}

measurements, $a$ priori expectations and sources

\begin{tabular}{lllll}
\hline & & \multicolumn{2}{c}{ Model } \\
S/no. & Variables and measurements & Bank credit & Gini index & Sources \\
\hline 1 & Real lending interest rate (\%) & negative & & WB (2016) \\
2 & Broad money growth (\%, annual) & positive & & WB (2016) \\
3 & Financial system deposits (\% of GDP) & positive & & WBGFDD (2015) \\
4 & Gross fixed capital formation (\% of GDP) & positive & & WB (2016) \\
5 & Domestic credit to private sector (\% of GDP) & & negative & WB (2016) \\
6 & Secondary enrolment (\%, total) & - & negative & WB (2016) \\
7 & Gini index & - & Lahoti et al. $(2016)$
\end{tabular}

Notes: WB: World Bank; WBGFDD: World Bank Global Financial Development Database

Source: Author's compilations

Table 2.

Summary statistics and correlation matrix

\begin{tabular}{lrrrrrrrrr}
\hline Variables & Mean & SD & Gini index & DC & RLR & BMG & FSD & GFCF & SEC \\
\hline Gini index & 56.565 & 4.000 & 1.000 & & & & & & \\
DC & 14.999 & 6.100 & 0.051 & 1.000 & & & & & \\
RLR & -4.622 & 26.711 & 0.038 & 0.220 & 1.000 & & & & \\
BMG & 24.403 & 17.275 & 0.485 & 0.171 & 0.038 & 1.000 & & & \\
FSD & 17.372 & 5.485 & -0.156 & 0.815 & 0.208 & -0.139 & 1.000 & & \\
GFCF & 12.718 & 6.415 & -0.441 & 0.071 & -0.024 & -0.365 & 0.402 & 1.000 & \\
SEC & 31.086 & 5.736 & -0.374 & 0.176 & -0.046 & -0.034 & -0.023 & -0.420 & 1.000
\end{tabular}

Notes: SD: standard deviation; DC: domestic credit; RLR: real lending interest rate; BMG: broad money growth; FSD: financial system deposits; GFCF: gross fixed capital formation; Sec: secondary enrolment Source: Author's computations 


\begin{tabular}{|c|c|c|c|c|c|c|}
\hline Variables & Level & $\begin{array}{l}\text { DF-GLS* } \\
\text { First diff. }\end{array}$ & Decision & Level & $\begin{array}{c}\text { PP } \\
\text { First diff. }\end{array}$ & Decision \\
\hline Broad money growth & $-3.578^{\mathrm{b}}$ & - & $I(0)$ & $-3.200^{\mathrm{b}}$ & - & $I(0)$ \\
\hline Real lending interest rate & $-4.785^{\mathrm{a}}$ & - & $I(0)$ & $-6.017^{\mathrm{a}}$ & - & $I(0)$ \\
\hline Domestic credit (log) & $-3.629^{\mathrm{b}}$ & - & $I(0)$ & $-2.812^{\mathrm{c}}$ & - & $I(0)$ \\
\hline Financial system deposits (log) & -2.639 & $-3.899^{\mathrm{a}}$ & $I(1)$ & -2.344 & $-5.254^{\mathrm{a}}$ & $I(1)$ \\
\hline Gini index $(\log )$ & -1.382 & $-4.436^{\mathrm{a}}$ & $I(1)$ & -1.201 & $-5.461^{\mathrm{a}}$ & $I(1)$ \\
\hline Gross fixed cap. formation (log) & -1.870 & $-6.489^{\mathrm{a}}$ & $I(1)$ & -2.866 & $-4.968^{\mathrm{a}}$ & $I(1)$ \\
\hline Secondary enrolment rate & $-2.890^{\mathrm{c}}$ & - & $I(0)$ & $-3.239^{b}$ & - & $I(0)$ \\
\hline
\end{tabular}

Notes: DF-GLS: Dickey-Fuller Generalised Least Squares; PP: Phillips-Perron; ${ }^{\text {a, b, c }}{ }^{\mathrm{c}}$ denotes statistical significance at $1 \%, 5 \%$ levels and 10\%, respectively. Estimations augmented with lag structures obtained from BIC using the varsoc routine in Stata. "Interpolated critical values from Elliot et al. (1996)

Source: Author's computations

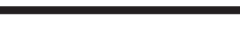

Table 3.

DF-GLS and PP unit root tests

\begin{tabular}{lcccccc}
\hline & \multicolumn{2}{c}{ ADF } & \multicolumn{2}{c}{$Z_{\mathrm{t}}$} & \multicolumn{2}{c}{$Z_{\mathrm{a}}$} \\
Gregory-Hansen models & Statistic & Break point & Statistic & Break point & Statistic & Break point \\
\hline Intercept shift (1) & $-5.48^{\mathrm{a}}$ & 2009 & $-5.34^{\mathrm{a}}$ & 2007 & -29.23 & 2007 \\
Intercept shift with trend (2) & $-5.55^{\mathrm{a}}$ & 2009 & $-5.42^{\mathrm{a}}$ & 2007 & -29.24 & 2007 \\
Intercept shift with slope (3) & $-5.51^{\mathrm{a}}$ & 2009 & $-5.51^{\mathrm{a}}$ & 2004 & -31.24 & 2004
\end{tabular}

Notes: ${ }^{a}$ denotes significance at $5 \%$ level. The $5 \%$ critical values for ADF (and $Z_{t}$ ) are $-4.92,-5.29$ and -5.50 for Models 1-3, respectively, while the $Z_{\mathrm{a}}$ for the same models are $-46.98,-53.92$ and -58.33 , respectively. Stata routine ghansen is used with optimal lag structure chosen by the BIC

Source: Author's computations

Table 4.

Gregory-Hansen cointegration test result

that a lower value evidences a better model. Hence, this study adopts the $\mathrm{Zt}$ results and uses 2007 as the breakpoint year. It is noteworthy to state that the identified and significant breakpoint in the year 2007 coincided with the post-consolidation period when the Central Bank of Nigeria $(\mathrm{CBN})$ initiated some recapitalisation policies, which increased the minimum share capital of banks from N 2bn to N 25bn. This policy led to severe shake-ups within the banking sector, culminating into merger and acquisition moves.

\subsection{Composite error correction model results}

This section presents the results for the models, namely, bank credit model, Gini index model and the augmented Gini index model. Table 5 Column [1] presents the results for the bank credit model where convergence to long-run equilibrium is at a speed of $69 \%$ with the adjustment term negative and statistically significant at the $1 \%$ level. Also, in the long-run, a percentage point increase in the real lending rate is associated with a reduction in the volume of bank credit by -0.0045 . This suggests that increasing the real lending rate by $1 \%$ point contributes about $0.045 \%$ decrease in bank credit, on average, ceteris paribus. This relationship is statistically significant at the $10 \%$ level and consistent with a priori expectations. In retrospect, to boost the volume of credit, the real lending rate must be reduced. Also, on average, ceteris paribus, financial system deposits (0.9745) is a positive predictor of bank credit while gross fixed capital formation negatively impacts bank credit 


\begin{tabular}{|c|c|c|c|}
\hline Variables & $\begin{array}{c}{[1]} \\
\Delta \text { Bank credit (log) }\end{array}$ & $\begin{array}{c}{[2]} \\
\Delta \text { Gini index (log) }\end{array}$ & $\begin{array}{c}{[3]} \\
\Delta \text { Gini index (log) }\end{array}$ \\
\hline Constant & $0.4851^{\mathrm{c}}(2.00)$ & $0.7914^{\mathrm{a}}(2.92)$ & $2.7147^{\mathrm{a}}(11.00)$ \\
\hline $\begin{array}{l}\text { Adjustment } \\
\text { Long-run estimates } \\
\text { Real lending interest rate } \\
\text { Broad money growth } \\
\text { Financial systems deposits (log) } \\
\text { Gross fixed capital formation (log) } \\
\text { Bank credit (log) } \\
\text { Secondary enrolment rate } \\
\text { Breakpoint dummy } \\
\text { Bank credit (log) } \times \text { breakpoint dummy } \\
\text { Secondary enroll. } \times \text { breakpoint dummy }\end{array}$ & $\begin{array}{c}-0.6904^{\mathrm{a}}(-5.01) \\
-0.0045^{\mathrm{c}}(-1.91) \\
0.0025(0.83) \\
0.9745^{\mathrm{a}}(7.11) \\
-0.3591^{\mathrm{a}}(-3.47)\end{array}$ & $\begin{array}{c}-0.0914(-0.925) \\
-0.0202^{\mathrm{b}}(-2.59)\end{array}$ & $\begin{array}{c}-0.0527^{\mathrm{a}}(-3.08) \\
0.0007(0.75) \\
-0.3628^{\mathrm{b}}(-2.49) \\
0.2251 \mathrm{a}(10.74) \\
-0.0109^{\mathrm{a}}(-3.44)\end{array}$ \\
\hline $\begin{array}{l}\text { Short-run estimates } \\
\Delta \text { Broad money growth } \\
\Delta \text { Broad money growth_1 } \\
\Delta \text { Financial systems deposits (log) } \\
\Delta \text { Gross fixed capital formation (log) } \\
\Delta \text { Bank credit (log) } \\
\Delta \text { Secondary enrolment rate } \\
\text { Bounds test } \\
\text { Observations } \\
R^{2}\end{array}$ & $\begin{array}{c}0.0011(0.60) \\
-0.0080 \mathrm{a}(-3.89) \\
1.0526^{\mathrm{a}}(4.15) \\
0.1423(1.37)\end{array}$ & $\begin{array}{c}0.0730^{\mathrm{a}}(4.17) \\
0.0005(0.40) \\
6.054^{\mathrm{a}} \\
34 \\
0.612\end{array}$ & $\begin{array}{c}0.0244^{\mathrm{a}}(2.23) \\
-0.0010(-1.52) \\
\text { N/A } \\
34 \\
0.93\end{array}$ \\
\hline $\begin{array}{l}\text { Durbin-Watson (autocorrelation) } \\
\text { Breusch-Godfrey (serial correlation) } \\
\text { White (heteroscedasticity) } \\
\text { ARCH LM (cond. heteroscedasticity) } \\
\text { Jarque-Bera (normality) } \\
\text { CUSUMSQ (stability) }\end{array}$ & $\begin{array}{c}1.844 \\
0.721 \\
0.418 \\
0.760 \\
0.835 \\
\text { Stable }\end{array}$ & $\begin{array}{c}2.509 \\
0.957 \\
0.036^{\mathrm{b}} \\
0.441 \\
0.0013^{\mathrm{a}} \\
\text { unstable with a break }\end{array}$ & $\begin{array}{l}1.729 \\
0.626 \\
0.495 \\
0.693 \\
0.586 \\
\text { stable }\end{array}$ \\
\hline \multicolumn{4}{|c|}{ 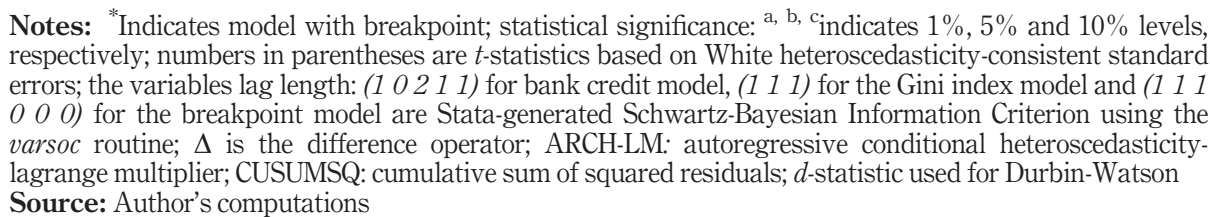 } \\
\hline
\end{tabular}

at the $1 \%$ significance level, respectively. The outcome of financial systems deposits is in line with a priori expectations while gross fixed capital formation contradicts. In the shortrun, the first lag of the broad money growth $(-0.080)$ and financial systems deposits $(1.053)$ have asymmetric effects on bank credit at the 1\% level; and the model shows a good fit as the regressors explain about $88 \%$ variation in bank credit.

On the impact of bank credit on income inequality, the results in Column [2], which makes no provision for structural break significantly differ from Column [3], which makes provision for a break in the model. Results in Column [2] reveal that in the long-run, the equalising impact of bank credit on income inequality is statistically not significant. At the same time, secondary enrolment rate $(-0.0202)$ has an equalising effect at the $5 \%$ level, on average, ceteris paribus. The short-run analysis shows that bank credit (0.073) intensifies 
income inequality at the $1 \%$ significance level. On the adjustment term, shocks to the Gini index are corrected at a convergence speed of $16.14 \%$. Finally, about $61.20 \%$ variation in the Gini index is explained by the regressors.

The results in Column [3] capture the structural break in the model. In the first instance, with the same number of observations, the value of the $R^{2}$ indicates that the independent variables explain $93 \%$ of the variation in the Gini index while adjustment to long-run equilibrium is at a speed of $64.8 \%$ indicating that shocks to the Gini index are corrected for faster in the augmented model at the 1\% significance level. The results underscore that in the long-run, the coefficient of domestic credit (-0.0527) show equalising impact on income inequality at the $1 \%$ level. This is an important finding evidencing the credit-inequality nexus. That is, at a higher credit level, income inequality falls in the long-run. Another significant result is that the coefficient of the breakpoint $(-0.3628)$ is statistically significant at the $5 \%$ level evidencing the presence of a break at that point and indicating a negative impact on income inequality.

Taking the first differential of the Gini index to bank credit gives an overall impact [1] of 0.1725 if the breakpoint dummy equals 1 and -0.0527 if the breakpoint dummy equals 0 . This is an important finding because it shows that events in the banking sector within the specified break date of 2007 have a dis-equalising impact on income inequality. This period coincides with the recapitalisation, consolidation, mergers and acquisition moves within the banking sector, which led to the recalling of outstanding obligations while further loan disbursements were curtailed. Contrarily, the secondary enrolment rate shows an equalising impact on inequality at the breakpoint. Nonetheless, as in Column [1], domestic credit (0.0244) intensifies inequality in the short-run. These results validate one of the motives for embarking on this study, which is to observe if the results significantly differ if there is no provision for a break in the model. It also proves that much information is lost from estimations when structural breaks are unaccounted. A clear difference is that domestic credit significantly improves income distribution, and such significance wanes when a structural break is not controlled for. This outcome will aid policymakers in evaluating either the success or impact of a programme or agenda. Diagnostic results shown in the lowest panel of Table 5 provide evidence that the models are stable with normally distributed residuals, and the model specifications do not suffer from autocorrelation, heteroscedasticity and autoregressive conditional heteroscedasticity. Hence, the findings from this study can be used for inferences. Conclusively, this study adds a new line of thought to the finance-inequality literature by unbundling the impact of interest rate and domestic credit on income inequality. The interest-credit-inequality dynamics suggests that the UN 2030 SDG 10 is achievable for Nigeria, and this reasoning is not implausible. Logically, it is expected that when the lending rate falls, financial intermediation improves to accommodate agents initially excluded, thereby increasing their economic opportunities, which reduces the inequality gap, ceteris paribus.

\subsection{Sensitivity checks}

Sensitivity checks are engaged to confirm the stability of the estimates when another interest rate proxy, interest rate spread, is used. The spread is the difference between the lending rate and the deposit rate. The expected a priori is that if the interest rate spread is high (an implication that the lending rate is higher than the deposit rate), there will be a contraction in credit intermediation as borrowers will be discouraged from borrowing due to high lending rate. Results are shown in Table 6.

From the results shown in Table 6, though the coefficient of interest spread is statistically not significant, its negative sign is an important contribution. This is somewhat consistent with earlier outcomes in Column [1] of Table 5, which asserts that a higher interest spread (an 


\begin{tabular}{lc} 
Variables & $\Delta$ Bank credit $(\log )$ \\
\hline Constant & $0.5613^{\mathrm{c}}(1.75)$ \\
Adjustment & $-0.5467^{\mathrm{a}}(-3.67)$ \\
Long-run estimates & \\
Interest rate spread & $-0.0238(-1.10)$ \\
Broad money growth & $0.0075 \mathrm{~b}(2.10)$ \\
Financial systems deposits (log) & $0.8740 \mathrm{a}(3.91)$ \\
Gross fixed capital formation (log) & $-0.3594^{\mathrm{a}}(-2.60)$ \\
Short-run estimates & \\
$\Delta$ Interest rate spread & $-0.0026(-0.18)$ \\
$\Delta$ Broad money growth & $-0.0002(-0.11)$ \\
$\Delta$ Broad money growth_1 & $-0.0072^{\mathrm{a}}(-3.19)$ \\
$\Delta$ Financial systems deposits (log) & $0.7619^{\mathrm{a}}(4.05)$ \\
$\Delta$ Gross fixed cap. form (log) & $0.1131(1.05)$ \\
Observations & 33 \\
$R^{2}$ & 0.867 \\
Bounds test & $4.077^{\mathrm{b}}$
\end{tabular}

Notes: $\Delta$ is the difference operator. Numbers in parentheses are $t$-statistics based on White heteroscedasticity-consistent standard errors. Statistical significance: ${ }^{a}$, b, cindicates $1 \%, 5 \%$ and $10 \%$

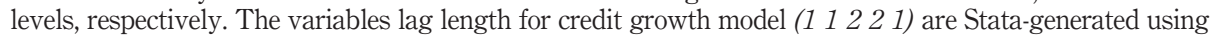
the varsoc routine. Diagnostic results: Breusch-Godfrey (for autocorrelation): 0.3234; White (heteroscedasticity): 0.4180; Autoregressive conditional heteroscedasticity-Lagrange Multiplier (ARCH-LM): 0.5780; Ramsey regression specification error test (RESET for omitted variables): 0.4515; Jarque-Bera (for normality): 0.8208; Variance inflation factor (VIF for multicollinearity): 1.46; Cumulative sum of squares

Table 6. (CUSUMSQ for stability): stable

Sensitivity checks Source: Authors' computations

indication of high lending rate) hampers the ability to generate credit. Broad money growth and financial systems deposits are in line with a priori expectations. At the same time, gross fixed capital formation has a significant negative effect on bank credit at the $1 \%$ level, on average, ceteris paribus. Other results indicate that in the short-run, broad money growth and financial systems deposits have asymmetric effects on bank credit at the $1 \%$ significance level. Also, the adjustment term $(-0.5467)$ is statistically significant at the $1 \%$ level, suggesting that errors are corrected within the year at a convergence speed of $55 \%$. Other diagnostic results reveal that there is a long-run cointegrating relationship at the $5 \%$ level (Bounds test), no evidence of autocorrelation, heteroscedasticity, autoregressive conditional heteroscedasticity, multicollinearity and no omitted variables. The model evidences a good fit with the $R^{2}$ value of 0.867 .

\section{Conclusion and policy implications}

Given the study scope, unbundling the interest-credit-inequality nexus takes a different approach, which makes the study unique. Using the ECM, findings show the channel of influence of interest rate on income inequality, which is an indirect relationship contrary to the direct relationship as currently postulated in the literature. Also, results reveal that bank credit is an outcome of interest rate adjustments, which has a negative and equalising impact on income inequality. Hence, the interest-inequality and credit-inequality relationships are unbundled given this transmission mechanism. Likewise, evidence shows that bank credit has a significant equalising impact on income inequality when a breakpoint is identified, and the model augmented. Ability to identify this salient feature prevents 
wrong inferences from being made, and this outcome will aid policymakers in evaluating either the success or impact of a programme or agenda.

As apex financial regulators, particularly central banks, are powerful because of their ability to redistribute wealth very quickly (Piketty, 2014), policy implications, which aid the achievement of 2030 SDG 10 are not far-fetched. First, the CBN can change interest rates, which invariably could moderate inequality (via interest rate reduction) or intensify income inequality (via interest rate increase). For instance, to mitigate the financial burden caused by the outbreak of the coronavirus, the $\mathrm{CBN}$ reduced the monetary policy rate (MPR) from $13.50 \%$ to $12.50 \%$ (Central Bank of Nigeria, 2020). It is expected that reducing the MPR, ceteris paribus, will have the multiplier effect of:

- reducing the lending rate,

- increase lending for greater financial intermediation,

- enhance financial inclusion and

- improve the economic welfare of poor households.

In the same vein, financial intermediaries can remove or relax administrative bottlenecks that pertain to accessing loan facilities such that those excluded can access credit and enhance their economic opportunities, thereby reducing income inequality. Overall, findings on income inequality are consistent with a priori expectations, and this study recommends that policies that will engender competitive lending interest rate be pursued to stimulate financial intermediation with inequality-reducing outcomes. For future research, the effect of credit access requires further empirical study, particularly the need to test for regulatory control both within the banking framework and on income inequality. This gap may be taken up in subsequent research.

\section{Note}

1. Overall impact is calculated as: ${ }^{\partial \text { Gini }} / \partial$ Bank Credit $=-0.0527+0.2251 d$; where $\mathrm{d}=$ breakpoint dummy.

\section{References}

Adeleye, N., Osabuohien, E. and Bowale, E. (2017), "The role of institutions in the finance-inequality nexus in Sub-Saharan Africa", Journal of Contextual Economics, Vol. 137 Nos 1/2, pp. 173-192.

Adeleye, N., Osabuohien, E., Bowale, E., Matthew, O. and Oduntan, E. (2018), "Financial reforms and credit growth in Nigeria: Empirical insights from ARDL and ECM techniques", International Review of Applied Economics, Vol. 32 No. 6, pp. 807-820, doi: 10.1080/ 02692171.2017.1375466.

Adusei, M. (2013), "Finance-Growth nexus in Africa: a generalised panel method of moments (GMM)", Analysis. Asian Economic and Financial Review, Vol. 3 No. 10, pp. 1314-1324.

AfDB (2012), "Income inequality in Africa. Briefing notes for AfDB's Long-Term strategy", Retrieved from www.afdb.org/fileadmin/uploads/afdb/Documents/Policy-Documents/FINAL\%20Briefing $\% 20$ Note $\% 205 \% 20$ Income $\% 20$ Inequality $\% 20$ in $\% 20$ Africa.pdf

Africa Tax and Inequality Report (2014), “Africa rising? Inequalities and the essential role of fair taxation”, Retrieved from www.taxjusticenetwork-Africa.org

Agnello, L., Mallick, S.K. and Sousa, R.M. (2012), "Financial reforms and income inequality", Economics Letters, Vol. 116 No. 3, pp. 583-587, doi: 10.1016/j.econlet.2012.06.005. 
Aigbokhan, B.E. (2000), Poverty, Growth, and Inequality in Nigeria: A Case Study, (Vol. 102): African Economic Research Consortium.

Aigbokhan, B.E. (2008), "Growth, inequality and poverty in Nigeria", Prepared for United Nations Economic Commission for Africa (UNECA), Addis Ababa, Ethiopia.

Bae, K., Han, D. and Sohn, H. (2012), "Importance of access to finance in reducing income inequality and poverty level", International Review of Public Administration, Vol. 17 No. 1, pp. 1-24.

Balassa, B. (1989), "Financial liberalisation in developing countries", in T.W.B. Development Economics (Ed.), (Working Paper, pp. 1-31). Washington, DC: Office of the Vice President.

Barro, R.J. (2008), "Inequality and growth revisited", Working Paper Series on Regional Economic Integration, Vol. 11 No. 1, pp. 1-24.

Batabyal, S. and Chowdhury, A. (2015), "Curbing corruption, financial development and income inequality", Progress in Development Studies, Vol. 15 No. 1, pp. 49-72.

Beck, T., Demirgüç-Kunt, A. and Levine, R. (2007), "Finance, inequality and the poor", Journal of Economic Growth, Vol. 12 No. 1, pp. 27-49, doi: 10.1007/s10887-007-9010-6.

Becker, G.S. and Tomes, N. (1979), "An equilibrium theory of the distribution of income and intergenerational mobility", Journal of Political Economy, Vol. 87 No. 6, pp. 1153-1189.

Becker, G.S. and Tomes, N. (1986), "Human Capital and the rise and fall of families", Journal of Labor Economics, Vol. 4 No. 3 Pt. 2, pp. 1-39.

Black, S.E. and Lynch, L.M. (1996), "Human-capital investments and productivity", American Economic Review, Vol. 86 No. 2, pp. 263-267.

Blanchflower, D. and Oswald, A. (1998), "What makes an entrepreneur", ? Journal of Labor Economics, Vol. 16 No. 1, pp. 26-60.

Blecker, R.A. (2008), "External shocks, structural change, and economic growth in Mexico 1979-2007", American University Working Paper Series, No. 2008-04, pp. 1-34.

Boateng, A. and Abdulrahman, M.D. (2013), "Micro small-sized enterprises and bank credit: evidence from West Africa", Journal of Emerging Market Finance, Vol. 12 No. 2, pp. 129-150.

Borozan, D. (2017), "Testing for convergence in electricity consumption across croatian regions at the consumer's sectoral level”, Energy Policy, Vol. 102, pp. 145-153, doi: 10.1016/j. enpol.2016.12.018.

Central Bank of Nigeria (2020), Central Bank of Nigeria Communiqué No. 130 of the Monetary Policy Committee Meeting of Thursday, May 28 2020, Abuja: Central Bank of Nigeria, Retrieved from www.cbn.org.

Chatterjee, S. and Turnovsky, S.J. (2012), "Infrastructure and inequality", European Economic Review, Vol. 56 No. 8, pp. 1730-1745, doi: 10.1016/j.euroecorev.2012.08.003.

Chipote, P., Mgxekwa, B. and Godza, P. (2014), "Impact of financial liberalization on economic growth: a case study of South Africa”, Mediterranean Journal of Social Sciences, Vol. 5 No. 23, pp. 1-8.

Chiwira, O., Bakwena, M., Mupimpila, C. and Thalefang, J.B. (2016), "Integration, inclusion, development in the financial sector and economic growth nexus in SADC: empirical review", British Journal of Economics, Management and Trade, Vol. 11 No. 4, pp. 1-15.

Dastidar, A.G. (2012), "Income distribution and structural transformation: empirical evidence from developed and developing countries", Seoul Journal of Economics, Vol. 25 No. 1, pp. 25-56.

Davtyan, K. (2016), Income Inequality and Monetary Policy: An Analysis on the Long Run Relation, Research Institute of Applied Economics Working Papers.

Delis, M.D., Hasan, I. and Kazakis, P. (2014), "Bank regulations and income inequality: empirical evidence”, Review of Finance, (2014), Vol. 18 No. 5, pp. 1811-1846, doi: 10.1093/rof/rft039.

Demirgüç-Kunt, A. and Levine, R. (2009), "Finance and inequality: Theory and evidence. National bureau of economic research, working paper 15275 ”, available at: www.nber.org/papers/ w15275. 
Dramani, J.B., Tandoh, F. and Tewari, D.D. (2012), "Structural breaks, electricity consumption and economic growth: evidence from Ghana", African Journal of Business Management, Vol. 6 No. 22, pp. 6709-6720, doi: 10.5897/AJBM11.2800.

Evans, D.S. and Jovanovic, B. (1989), "An estimated model of entrepreneurial choice under liquidity constraints”, Journal of Political Economy, Vol. 97 No. 4, pp. 808-827.

Frey, L. and Volz, U. (2013), "Regional financial integration in Sub-Saharan Africa - An empirical examination of its effects on financial market development", South African Journal of Economics, Vol. 81 No. 1, pp. 1-39.

Galor, O. and Moav, O. (2006), "Das human kapital: a theory of the demise of the class structure", Review of Economic Studies, Vol. 73 No. 1, pp. 85-117.

Gine, X. and Townsend, R. (2004), "Evaluation of financial liberalisation: a general equilibrium model with constrained occupation choice", Journal of Development Economics, Vol. 74 No. 2, pp. 269-307.

Greenwood, J. and Jovanovic, B. (1990), "Financial development, growth and the distribution of income", Journal of Political Economy, Vol. 98 No. 5, Part 1, pp. 1076-1107.

Gregory, A.W and Hansen, B.E. (1996), "Residual-based tests for cointegration in models with regime shifts", Journal of Econometrics, Vol. 70 No. 1, pp. 99-126.

Holtz-Eakin, D., Joulfaian, D. and Rosen, H.S. (1994), "Sticking it out: Entrepreneurial survival and liquidity constraints", Journal of Political Economy, Vol. 102 No. 1, pp. 53-75.

IMF (2010), Unemployment Dynamics during Recession and Recoveries: Okun's Law and Beyond, (pp. 1-40). Washington, DC: International Monetary Fund.

Iossifov, P. and and Khamis, M. (2009), "Credit growth in Sub-Saharan Africa - Sources, risks, and policy responses”, IMF Working Paper, WP/09/180, 1-30.

Kar, S. and and Saha, S. (2012), "Corruption, shadow economy and income inequality: evidence from asia", The Institute for the Study of Labor (IZA), IZA Discussion Paper No. 7106.

Kolawole, B.O., Omobitan, O.A. and Yaqub, J.O. (2015), "Poverty, inequality and rising growth in Nigeria: further empirical evidence", International Journal of Economics and Finance, Vol. 7 No. 2, pp. 1-12.

Kripfganz, S. and Schneider, D.C. (2016), "ARDL: Stata module to estimate autoregressive distributed lag models", Paper presented at the Stata Conference, Chicago, July 29, 2016.

Lahoti, R., Jayadev, A. and Reddy, S.G. (2016), "The global consumption and income project (GCIP): an overview", Available at SSRN, Vol. 1 No. 1, pp. 1-43, available at: https://ssrn. com/abstract= 2480636, Retrieved from www.gcip.info

Levine, R. (2008), "Finance and the poor", Manchester School, Vol. 76, pp. 1-13.

$\mathrm{Li}, \mathrm{J}$. and $\mathrm{Yu}, \mathrm{H}$. (2014), "Income inequality and financial reform in Asia: the role of human Capital", Applied Economics, Vol. 46 No. 24, pp. 2920-2935, doi: 10.1080/00036846.2014.916390.

Lo Prete, A. (2013), "Economic literacy, inequality and financial development", Economics Letters, Vol. 118 No. 1, pp. 74-76, doi: 10.1016/j.econlet.2012.09.029.

McKenzie, D.J. and Woodruff, C. (2006), "Do entry costs provide an empirical basis for poverty traps? evidence from mexican microenterprises", Economic Development and Cultural Change, Vol. 55 No. 1, pp. 3-42.

Mercy Corps (2015), "The economic costs of conflicts and the benefits of peace: effects of FarmerPastoralist conflict in Nigeria's middle belt on state, sector and national economies", Retrieved from www.mercycorps.org/ . ./Mercy $\% 20$ Corps $\% 20$ Nigeria $\% 20$ Household $\% 20$ Costs, Portland, OR

Nuruddeen, T. and Ibrahim, S.S. (2014), "An empirical study on the relationship between poverty, inequality and economic growth in Nigeria", Journal of Economics and Sustainable Development, Vol. 5 No. 26, pp. 1-6. 
Odedokun, M.O. and and Round, J.I. (2001), "Determinants of income inequality and its effects on economic growth: evidence from African countries", Working Paper: UNU/WIDER.

Odhiambo, N.M. (2014), "Financial systems and economic growth in South Africa: a dynamic complementarity test", International Review of Applied Economics, Vol. 28 No. 1, pp. 83-101.

Ogbeide, E.N.O. and Agu, D.O. (2015), "Poverty and income inequality in Nigeria: any causality? ", Asian Economic and Financial Review, Vol. 5 No. 3, pp. 439-452.

Olusegun, A.J., Akintoye, I.R. and Dada, S.O. (2014), "Commercial bank credit and sectoral growth in Sub-Saharan africa: Evidence from Nigeria", Global Advanced Research Journal of Management and Business Studies, Vol. 3 No. 9, pp. 423-431.

Orji, A., Aguegboh, E. and Anthony-Orji, O.I. (2015), "Real sector output and financial liberalisation in Nigeria", Journal of Infrastructure Development, Vol. 7 No. 2, pp. 136-150.

Osahon, S. and Osarobo, A.K. (2011), "Poverty and income inequality in Nigeria: an empirical assessment", JORIND, Vol. 9 No. 2, pp. 1-9.

Østergaard, S.F. (2013), "The determinants of income inequality: a Sub-Saharan perspective", (MSc Unpublished Thesis), Aarhus University.

Pesaran, M.H., Shin, Y. and Smith, R.P. (2001), "Bounds testing approaches to the analysis of level relationship", Journal of Applied Econometrics, Vol. 16 No. 3, pp. 289-326.

Piketty, T. (2014), Capital in the Twenty-First Century, Cambridge, MA: Harvard University Press.

Sbia, R., Shahbaz, M. and Ozturk, I. (2017), "Economic growth, financial development, urbanisation and electricity consumption nexus in UAE”, Economic Research-Ekonomska Istraživanja, Vol. 30 No. 1, pp. 527-549, doi: 10.1080/1331677X.2017.1305792.

van der Hoeven, R. (2010), "Income inequality and employment revisited: can one make sense of economic policy?", Journal of Human Development and Capabilities, Vol. 11 No. 1, pp. 67-84, doi: $10.1080 / 19452820903481459$.

World Bank (2015), World Development Indicators, World Bank. Retrieved May 09, 2016, from World Bank.

World Bank (2016), World Bank Global Financial Development Database, available at: www.worldbank. org/en/publication/gfdr/data/global-financial-development-database

\section{Further reading}

Balassa, B. (1990), "Financial liberalisation in developing countries", Studies in Comparative International Development, Vol. 25 No. 4, pp. 56-70.

McKinnon, R.I. (1973), Money and Capital in Economic Development, Washington, DC: Brookings Institution.

Shaw, E.S. (1973), Financial Deepening in Economic Development, New York, NY: Oxford University Press.

\section{Corresponding author}

Bosede Ngozi Adeleye can be contacted at:ngozi.adeleye@covenantuniversity.edu.ng

For instructions on how to order reprints of this article, please visit our website:

www.emeraldgrouppublishing.com/licensing/reprints.htm

Or contact us for further details: permissions@emeraldinsight.com 